\title{
Literaci i prasa warszawska pod pręgierzem satyry Gustawa Daniłowskiego
}

Grażyna Legutko 
NAP7S Seria XIV 2008

\author{
Grażyna Legutko
}

\title{
Literaci i prasa warszawska pod pręgierzem satyry Gustawa Daniłowskiego
}

$\mathrm{W}$ ykorzystujący różnorodne techniki literackie (od zapisu realistycznego i relacji faktograficznej, przez impresjonistyczne utrwalanie wrażeń i operowanie elementami poetyki wzniosłości, do posługiwania się parabolą i symbolem) Gustaw Daniłowski rzadko sięgał po narzędzie chłoszczącej satyry. Twórczość tego młodopolskiego pisarza - „poety miecza, młota i orlego śpiewu”, na jakiego pasował go ongiś Brzozowski - związana przede wszystkim (choć nie wyłącznie) z problematyką rewolucyjno-niepodległościową, przesycona jest bowiem tonacją ponurą, pozbawioną zazwyczaj akcentów komicznych. Powieściowe kreacje rewolucyjnych straceńców i męczenników narodowej Sprawy wydobywają z reguły rysy tyrtejskie albo realizują etos "człowieka podziemnego"2, wobec którego pisarz nigdy nie zajmuje stanowiska prześmiewcy.

$\mathrm{Na}$ tym tle ciekawiej rysują się — funkcjonujące na prawach wyjątku - ujęcia satyryczne. Co znamienne, Daniłowski zaczyna po nie sięgać w czasach przedrewolucyjnego wrzenia i w burzliwych latach rewolucji 1905-1907 — próbując, na zasadzie terapii śmiechem, przynajmniej częściowo oswoić chaos otaczającego świata. Przeważnie ujęcia owe odwołują się do sytuacji dotyczących zwyczajnego (nie-rewolucyjnego) życia. Spośród nich najbardziej zajmujące wydają się kreacje literatów-nieudaczników i sarkastyczne uwagi na temat ówczesnej prasy warszawskiej. Zajmujące tym bardziej,

${ }^{1}$ S. Brzozowski, Wspótczesna powieś́ i krytyka, wst. T. Burek, Kraków-Wrocław 1984, s. 457.

${ }^{2}$ Mówiąc o etosie rewolucjonisty, mam na myśli przede wszystkim zespół norm i wartości zrekonstruowany przez Bohdana Cywińskiego w pracy Rodowody niepokornych, Paryż 1985, (zob. zwłaszcza refleksje w rozdziale Ethos ludzi podziemnych, s. 95-153). 
że pokazują mniej znane oblicze Daniłowskiego, twórcy uważanego przede wszystkim za barda rewolucji (jako autora Jaskótki), skandalistę i gorszyciela opinii publicznej (za sprawą niecenzuralnej Marii Magdaleny) czy ideologa PPS-Frakcji Rewolucyjnej (dzięki zbiorowi zbeletryzowanych biografii Bandyci z PPS).

Warto zatem przyjrzeć się Daniłowskiemu jako twórcy prozy artystowskiej, dla którego fikcja literacka stwarzała dogodną okazję do zapisu przeżyć osobistych związanych z profesją pisarza. Na podstawie analizy tego wycinka jego twórczości można jednocześnie $\mathrm{z}$ powodzeniem, jak sądzę, pokazać w krzywym zwierciadle symptomatyczne znamiona kultury fin de siècle'u.

Nadrzędnym zagadnieniem oświetlanym satyrycznie w prozie Daniłowskiego jest pojęcie sztuki jako „targowiska próżności”, modnego artykułu, którym się kupczy. Wyrazicielem poglądów pisarza w tej kwestii jest jeden z bohaterów Jaskótki (1907) - renegat ruchu rewolucyjnego, sfilistrzały, ale jasno rzecz widzący, cyniczny panicz Orski. Sprawując funkcję swoistego mecenasa sztuki, urządza w swym warszawskim mieszkaniu spotkania literackie, a mówiąc precyzyjniej: biby dla artystycznego światka stolicy. Stwarzają one sposobność bliższego oglądu różnych „okazów” tego światka. Znajdujemy wśród nich literatów-nieudaczników i tandeciarzy, męczeńskie ofiary i kabotynów ${ }^{3}$, błaznów jarmarcznych i psychopatów, by uciec się do znanej klasyfikacji Marii Podrazy-Kwiatkowskiej4.

Przykładem psychopaty i nieudacznika zarazem jest Zimnicz — niepłodny twórczo neurastenik; ofiary zaś - wykolejony artysta-alkoholik Warski, niegdyś ceniony autor natchnionych dzieł, który zwichnął sobie karierę przez filisterskie pożycie rodzinne ${ }^{5}$ i zdegradował się do roli gazetowego korektora. Radząc młodszemu (zdolnemu) koledze, jak osiągnąć sławę (i jednocześnie ocalić talent), Zimnicz przekonuje sarkastycznie:

Ty może jeszcze, siadając do pisania, modlisz się o łaskę niebios!... Głupstwo! jeśli chcesz wyjechać wysoko, módl się o łaskę Gebethnera i Wolffa,

3 Oczywiście w „prozie artystowskiej” Danilowskiego występują też postacie artystów twórczych i spełnionych, realizujących ideowe posłannictwo sztuki (np. Orwid i Kwaszewski z Jaskótki, Janusz Tarczyński z opowiadania Za ściana, utalentowana skrzypaczka Stella Roini oraz Henryk — pierwszoosobowy narrator z Luźnych kartek). Zazwyczaj pojawiają się w typowej dla młodopolskiej literatury opozycyjnej relacji do filisterskiego tłumu lub artystów-improduktywów; często medium (katalizatorem) ich twórczości staje się ukochana kobieta. Artyści ci traktowani są przez Daniłowskiego serio, co wyklucza ich z kręgu niniejszej analizy.

${ }^{4}$ Zob. M. Podraza-Kwiatkowska, Bóg, ofiara, cloun czy psychopata? O roli artysty na przełomie XIX i XX wieku w: eadem, Mtodopolskie harmonie i dysonanse, Warszawa 1969, s. 246-276.

${ }_{5}$ Żona Warskiego nosi zresztą to samo imię, co żona Borowskiego z Berentowskiego Próchna - Zosia. Przegrany artysta mówi o niej: „Tak klektała, zaklekotała, zawaliła mi głowę rondlami, dyszkiem, praniem”; o sobie zaś: „bydlę skończone jestem, słabe, parszywe! Tak, pijak ze mnie, łajdak i włóczęga [...] żona mi się w pracy zarzyna, dzieci - bez portek... Czworo mam" (G. Daniłowski, Jaskótka, Kraków [1907], s. 366, 370). 
[...] brykaj, póki czas, bo jak cię zaraza morowa kurierów ogarnie zdechl pies! co pies! niejeden lew zadusił się i sparszywial... Pudle mają odbyt, bo to i zmyślne do każdej sztuki, i potulne... ${ }^{6}$

Typ jarmarcznego błazna uosabia $\mathrm{z}$ kolei blady poeta Jarecki - autor niewydanej powieści Męczennica, o której Warski mówi dowcipnie:

poronione w czwartym, a może nawet drugim miesiącu, płód z gruntu martwy [J, s. 363].

Drwiąc z jego nieznośnej lekkości pióra i prostytuowania sztuki, dodaje:

Wiesz pan dlaczego on taki blady? [...] bo ma solitera; rymowanego tasiemca, co numer na trzydzieści do pięćdziesięciu wierszy robaka wypuszcza, głowa zostaje, i przez dobę tyleż, co stracił odrasta... Po dziesięć kop. - trzy do pięciu rubli dziennie na tej jednej chorobie, szczęściarz, zarabia, a chciałby jeszcze prozą... [J, s. 364].

Najniebezpieczniejszym jednak typem literatów są — wedle Daniłowskiego - tzw. „ludzie słowa”, pełniący podrzędne role na rautach i fajfoklokach, reprezentanci artystycznego „chóru i tłumu”, którzy potrafią przerabiać

na gładki, płynny, a nieraz trafny i dowcipny frazes wszystko, co zajdzie w rogatkach Warszawy i przez lamy pism, salony, saloniki, cukiernie i gabinety restauracyjne dostarczać do szerszego ogółu, jako przeciętną opinię, obowiązującą na dziś każdą inteligentną jednostkę [J, s. 352].

Ich szczególną odmianę stanowią literaci prasowi, pozbawieni własnych poglądów, tolerancyjni w każdej sprawie i pod każdym względem, stanowiący

rdzenną cząstkę tej ruchliwej grupy, która słyszy wszystko i jest słyszana wszędzie, nastraja ton ogólu i dostraja się do niego sama, jest, jednym słowem, jednocześnie i głosem i echem, twórcą pewnej atmosfery w umiarkowanych strefach Warszawy, a zarazem płucem, które jej miazmatami najłatwiej oddycha [J, s. 353].

Prowadzone na rautach u Orskiego rozmowy na temat modelu współczesnej sztuki wpisują się w głośną młodopolską dyskusję dotyczącą europeizacji rodzimej literatury. Opozycję: „swojskość - europejskość” roztrząsa w powieści mizerny literat („trochę nowelista - trochę poeta”) o znaczącym nazwisku Rosset, żądający bezwzględnej „de-

${ }^{6}$ Ibidem, s. 365. Dalej lokalizacja stronicowa w nawiasie, bezpośrednio po cytacie, ze skrótem: J. 
zynfekcji prądów europejskich”, zwłaszcza symbolizmu, przy tym „połykając, nie wiadomo kiedy, masę przekąsek" [J, s. 354]. Daniłowski drwi z pseudo-erudycji literackiej bohatera, ujawniając płytkie rozumienie przez niego prądu jako nieznośnej mody towarzyskiej, napuszonego cudactwa, które sprowadza się do egzotycznych kombinacji słownych. Rosset daje towarzystwu dowcipny przepis na wiersz symbolistyczny, proponując

Chmiel zastąpić pnączem, a jeszcze lepiej lianami, wodne ziele grążelem lub mistycznym nenufarem; skakanie — rzucaniem się; kochanka — lubieżnikiem itd., jednym słowem, zamiast naturalnego wdzięku dać wykrygowany dziwolagg... [J, s. 354].

Prezentacja zdezintegrowanego światka artystycznego stolicy jest w Jaskótce jedynie epizodycznym elementem fabuły, służącym intensyfikacji obrazu chaosu świata, zamętu i bezideowości czasów przedrewolucyjnych. Jako temat samodzielny, oś konstrukcyjna fabuły, pojawia się natomiast w opowiadaniu Luźne kartki (1914), pisanym również w charakterystycznym momencie dziejowego zawirowania: tuż przed wybuchem Wielkiej Wojny (pełni więc analogiczną funkcję: komentuje w sposób aluzyjny „odchyloną od normy" - jak artyści ${ }^{7}$ — rzeczywistość historyczną). Literatów w tym utworze poznajemy w typowej scenerii kawiarniano-knajpowej, podczas nocnych birbantek, na których przede wszystkim pije się i „gada przeważnie o niczym", i najzabawniej jest, gdy ktoś się z kimś pokłóci. Wyróżniają się wśród nich: Wrocki — „pęcherz dziennikarski, gruchoczący w potrzebie rymami” [Lk, s. 8]; Żosicki, laureat nagrody literackiej „piramidalny małpiszon”, „,szewc ostatniego gatunku, a nie artysta” [Lk, s. 8], cieszący się bowiem, jak przystało na kabotyna, powodzeniem własnej osoby, a nie wyróżnionej powieści; Zemler — niewykwalifikowany krytyk literacki — „skończony rzezimieszek” [Lk, s. 11], piszący dla zarobku sprawozdania, sprowadzające się do nieudolnego opowiadania treści dzieł, mogący jednak każdego twórcę „schlastać, zarżnąć, posypać solą i pieprzem i połknąć” lub „oskalpować tak, że nieprędko zapuści czuprynę” [ibidem]; i wreszcie wodzący rej wśród zgrai pseudo-artystów cynik Rudzki — ,jakoby filozof", który otrzymał swą rangę „czysto honorowo, w braku innej” [Lk, s. 12].

Podstawową „twórczością" owej literackiej bandy są, jako się rzekło, zakrapiane alkoholem kabotyńskie rozmowy o niczym. Narrator zauważa z odrazą:

"Rozbierano" w ścisłym słowa tego znaczeniu sztukę i lubowano się kolejno jej wdziękami w sposób obrzydliwy.

Nie było w tym ani krzty uwielbienia, namiętnego porywu uniesienia,

\footnotetext{
7 Por. A. Makowiecki, „Antystostwo” jako odchllenie od normy, w: idem, Młodopolski portret artysty, Warszawa 1971, s. 158-177.

${ }^{8}$ G. Daniłowski, Luźne kartki. Nowele [opowiadanie tytułowe zbioru], Warszawa 1926, s. 11. Dalej lokalizację ze skrótem: Lk i numerem strony podano w nawiasie, po cytacie.
} 
który pragnie owladnąć i sam się całkowicie oddaje, lecz jakby lubieżność, rozkoszowanie się każdym poszczególnym dreszczykiem, wyrafinowana rozpusta zużytych starców, których coś wreszcie zdołało podniecić [Lk s. 13-14].

„Wydrążeni duchowo" literaci, pozbawieni myślowej głębi i talentu artystycznego, wydają się „zbutwiali” - jak mówi Danilowski, nawiązując aluzyjnie do znanej diagnozy z Próchna Berenta - mają „owrzodzoną duszę” i są ,jak skały zwietrzałe, które sypią się w gruzy i proch niemocy" [Lk, s. 14]. Co więcej, nie odczuwają nawet więzi między sobą — są „przyjaciólmi” od knajpy, spódniczki, pióra, ale nie od serca. W przypływie szczerości główny bohater Luźnych kartek zarzuca koledze emocjonalny fałsz, pozorną wrażliwość, pseudo-empatię wykolejoną w bladze literackiej, dokonując jednocześnie uogólnionej oceny światka artystycznego (niepozbawionej elementów czarnego humoru i karykaturalnej groteski):

Gdybym jutro zginął, byłbyś w stanie wycyzelować z tego powodu rzewne wspomnienie, bo w tobie już się wszystko transponuje na wiersze. Masz cerę jak bibuła, farbę drukarską w żyłach, zatrułeś się ołowiem czcionek i tym jadowitym wyziewem zaraziłeś mnie... Jak koloraturowej śpiewaczce drga w gardle tryl, tak nam się ciągle skręca język we frazes. Wielkie słowa bełtają się w zbutwiałej piersi. Zanurzeni poszyję w gnojowisku, możemy z bezczelną swobodą deklamować hymny do słońca. Myszkujemy po ranach ludzkich, po najdyskretniejszych zakątkach zbolałego serca, by wyłupać stamtąd pomys 1 do nowelki!... [wyróżn. - G. L.] Ty byś dla sensacji na dwie szpalty spalił Warszawę, nowożytny Neronie, kurierkowy Cezarze! Kochankę byś zarżnął za nowy ton, brata rozpruł dla świeżego porównania... Po hulaszczej nocy w tingel-tanglu, przy biurku stajesz się święty i ronisz na temat rozpusty atramentowe łzy, wstrętne, jak kleksy!... Ciebie z daleka czuć czernidłem; patrz! Włosy ci się jeżą jak istne stalówki; uważaj, bo się rozlecisz: jesteś cały pocięty na paski, szpalty; za dziesięć kopiejek od wiersza wnet się rozwijasz z niczego, jak papierowy wąż w ręku magika!... [Lk, s. 19]

W krzywym zwierciadle ukazuje się zatem sztuka sprostytuowana, tworzona z myślą o uciesze gawiedzi, pozbawiona godności i wzniosłości, sztuka kabotyńska, którą „lechce pochlebny bełkot ulicy” [Lk, s. 21]. Jej wytwórcami są sprytni pismacy, artyści-improduktywi, literaccy figuranci, marionetki, żonglerzy słowa, intelektualni ekshibicjoniści, uszminkowani clowni. 
Satyryczny portret literatów przynoszą też dwa inne opowiadania Danilowskiego: Zelma (1912) i Laureat (1905), w których uwaga pisarza skupia się nie tyle na prezentacji szerszej zbiorowości artystów, ile na pojedynczych indywiduach. W przypadku obu fabul mamy do czynienia z rozwiązaniem tragicznym: egzystencjalnym unicestwieniem, z tym że kabotyński literat z Zelmy doprowadza do samobójczej śmierci kobietę, która go kocha, tytułowy bohater Laureata unicestwia natomiast sam siebie.

Bohater Zelmy, „tak zwany poeta Mirski”, portretowany jest początkowo na tle artystycznej drużyny, którą tworzą ludzie młodzi, przeważnie uzdolnieni, ale wykolejeni, „idący na przepadle” [Z, s. 53] - aktor, grający podrzędne role z powodu przepitego gardła; śpiewak z bożej łaski, bez szkoły muzycznej i z ochrypłym głosem; malarz, który po zdobyciu srebrnego medalu na jednej z wystaw nie może się posunąć ani o krok dalej itp. Mirski wyróżnia się wśród nich nadmiarem smutku oraz pewnym talentem poetyckim, jednak jego wiersze są tak dziwaczne, że redaktorzy pism zamieszczają je rzadko, gdzieś na szarym końcu swych dzienników, w lukach, które można zapełnić byle czym, lub cytują je dla śmiechu w odpowiedziach od redakcji. Łączy go zaś z kompanią wykolejeńców skłonność do zalewania „wspólnego wszystkim robaka braku uznania" [Z, s. 54]. I w tym wszakże znamionują go odstające od innych reakcje - narrator zauważa dowcipnie:

Podczas gdy towarzysze jego po odpowiedniej dozie kieliszków nabierali niezwykłej pewności siebie i fantazji: śpiewak porywał się do arii operowych, aktor przedstawiał bohaterów Szekspira, malarze uraggali od mydlarzy wszelkim mistrzom, odgrażając się, że oni im dopiero pokażą - Mirskiego, w miarę potęgowania się hulaszczej atmosfery, ogarniał coraz cięższy, beznadziejny smutek — brał głowę w dłonie i zalewał się łzami, otwieral - jak dowcipkowano — destylarnię [Z, s. 54-55].

Ukojenie „beznadziejnego smutku” Mirski znajduje w ramionach niezwykle wrażliwej na poezję prostytutki (znającej na pamięć wiersze francuskich symbolistów), która pomaga mu wydać pierwszy zbiorek poezji. Zadufany w sobie egoista-kabotyn nie zauważa morderczych wysitków kochanki w celu zdobycia odpowiednich funduszy na ten cel, a także jej bezgranicznej miłości. Po osiągnięciu celu (wydrukowaniu tomiku) odtrąca dziewczynę, doprowadzając ją tym samym do samobójstwa.

Tragedią kończy się też historia innego poety-improduktywa, z przywołanego wyżej opowiadania Laureat. Jego tytułowy bohater jest oryginalnym przykładem symbiozy artysty i episjera, i jako taki odbiega od typowego w modernizmie konfliktu: jednostka twórcza - filisterski tłum. Jest jednocześnie urzędnikiem ubezpieczeniowym i lite-

${ }^{9}$ Idem, Zelma, w: idem, Epilog, Warszawa 1914, s. 54. Dalej lokalizacja podana w nawiasie, ze skrótem: $\mathrm{Z}$ i numerem strony. 
ratem, mającym latwość pisania (niewspółgrającą z talentem artystycznym). Dyrekcja biura ubezpieczeń, w którym pracuje, docenia jego „zdolności” pisarskie, powierzając mu redakcję ogłoszeń, korektę ortograficzno-stylistyczną raportów itp. odpowiedzialne czynności, przy których Siwiński doznaje „wzruszeń autora, redaktora i cenzora w jednej osobie” ${ }^{10}$. Jego próżność i „żarłoczne instynkty pychy” [L, s. 13] nasilają się w momencie wyróżnienia jego dramatu przez sąd konkursowy „Kuriera Porannego”. Nagrodzony, pod wpływem „odurzającego zapachu sławy” [L, s. 17], zaczyna marzyć o swej wielkości. Bolesne milczenie, które rychło następuje po chwilowym sukcesie, doprowadza go do stanu nieznośnej apatii. Narrator zaznacza humorystycznie:

Wyniesiony cudzymi rękami powyżej właściwej sobie miary, Siwiński według praw ciążenia musiał spaść do normalnego poziomu; nie mógł tego jednak ani zrozumieć, ani tym bardziej z naturalnym biegiem rzeczy się zgodzić.

Rozjuszona powodzeniem hydra pychy domagała się wciąż świeżej strawy [L, s. 23].

Siwiński postanawia więc napisać nowe dzieło, którym zamierza rzucić publiczność na kolana i ponownie upoić się triumfem sławy. Niestety, jałowa gra jego ubogiej wyobraźni długo nie podsuwa mu żadnego tematu. W końcu wpada na karkołomny pomysł - postanawia napisać tragedię przedstawiającą losy młodego poety, który zdobywa nagrodę konkursową, przez co wzbudza powszechną zawiść; szykanowany na każdym kroku zostaje doprowadzony do tego, że odbiera sobie życie, wieszając się na sznurku z zeschniętego wieńca laurowego. Indolencja twórcza uniemożliwia jednak dramaturgowi literacką realizację owego pomysłu. Satyryczna prezentacja daremnych wysilków Siwińskiego wydobywa takie cechy jego charakteru, jak: pozerstwo, bufonada, kabotyńskie odurzanie się własną mocą (oraz alkoholem), próźność, neurotyczna egzaltacja itd. Wkrótce satyra przekształca się w tragifarsę: bohater postanawia odwrócić kolejność wydarzeń wymyślonej sztuki i czyni jej final początkiem, sprawdzając uprzednio, co może czuć człowiek, który popełnia samobójstwo. Zaczyna (jak Borowski w Próchnie Berenta) „grać” rolę, a ponieważ jest to próba generalna, gra na serio..., za co otrzymuje wymarzony aplauz. Opowiadanie puentuje tragiczna ironia:

Mocno trącone rusztowanie rozsypało się, szeleszcząc bibułą. Siwiński wyprężył się. Wolnym, przeciąłym ruchem podkuliły się nogi... Grzmot frenetycznych oklasków zadudnił mu pod czaszką i piorunem zapadła ciężka, ołowiana kurtyna, zasłaniając wszystko na wieki [L, s. 34].

${ }^{10}$ Idem, Laureat, w: idem, Nad unviskiem. Wybór nowel, Warszawa 1922, s. 13. Dalej lokalizacja cytatów podana w nawiasie, ze skrótem: L i numerem strony. 
Koncepcja fabularna Laureata wykrystalizowała się w umyśle Daniłowskiego po konkursie na utwór humorystyczny, ogłoszonym przez redakcję „Tygodnika Ilustrowanego", w którym pisarz wziął udział i znalazł się w ścisłym gronie laureatów ${ }^{11}$. Nagrodzoną pracą Daniłowskiego było opowiadanie zatytułowane prosto: Humoreska ${ }^{12}$. Przedstawiało historię starego kawalera — filistra, który osiedliwszy się na stałe w Warszawie postanowil (w poczuciu obywatelskich obowiązków) popierać piśmiennictwo krajowe, wnosząc roczną przedpłatę na różne miejscowe czasopisma. Prezentowany przez narratora nieład wśród gromadzących się w mieszkaniu pana Mateusza (w zatrważającym tempie!) „stosów drukowanej bibuły”" ${ }^{13}$ korespondował aluzyjnie z zamętem przedrewolucyjnym:

po kilku tygodniach na stole zapanował kompletny chaos: numery „Roli” pomieszały się z „Niwą” i „Izraelita”, ,Goniec” poplątał się z „Kurierem”, a płachty „Słowa” przykrywały zeszyty tygodników postępowych [H, s. 119].

Na ciasnej przestrzeni znalazły się zatem pomieszane ze sobą egzemplarze: bojowego tygodnika antysemickiego i filosemickiego organu pozytywistów (obok pisma wyznaniowego dla Żydów garnących się do asymilacji), dziennika o profilu endeckim i bezprogramowego brukowca, ugodowego pisma ziemiaństwa i tygodników propagujących działania rewolucyjno-niepodległościowe. Budując gradację napięcia i wykorzystując technikę suspensu, w połączeniu z różnymi odmianami komizmu (głównie sytuacyjnego i słownego), Daniłowski osiąga zamierzone efekty satyryczne, przekształcając w końcu humoreskę w tragifarsę. Jej akcja właściwa rozpoczyna się ostatniego dnia kończącego się roku, kiedy posłańcy „,szczodrobliwych” redakcji zarzucają oszołomionego abonenta promocyjnymi dodatkami do swych czasopism. „Tygodnik Ilustrowany” dostarcza mu dwanaście tomów Sienkiewicza i tuzin dzieł naukowych; „Gazeta Polska" zasypuje stosami Historii sztuki, woluminami Ziemi zamieszkanej przez Polaków i całą „Biblioteką Dzieł Wyborowych”; „Wędrowiec” ofiarowuje monstrualne płótno (z zamalowaną na czarno płaszczyzną) przedstawiające szyb opuszczonej kopalni. „Lekarz Domowy” proponuje jako roczne premium wybór „czystych kultur niektórych zarazków" [H, s. 123] — chorób pierwszorzędnych, egzotycznych, takich jak: trąd skandynawski, azjatycka cholera, żółta febra i czarna ospa oraz przypadłości minorum

$11 \mathrm{Na}$ nagrodę dla zwycięzcy konkursu (oprócz honorarium autorskiego) przeznaczono 200 rubli. Ze 134 utworów, które napłynęły do redakcji, nie wybrano jednak dzieła zwycięskiego i kwotę przeznaczoną dla zdobywcy pierwszego miejsca rozdzielono na nagrody dla trzech autorów: Wincentego Rapackiego (juniora), Jana Lemańskiego i Gustawa Daniłowskiego. Zob. Nasz konkurs, „Tygodnik Ilustrowany" 1904 nr 12 oraz W. Giełżyński, Prasa warszawska 1661-1914, Warszawa 1962, s.102.

12 Opowiadanie zostało opublikowane w 1905 roku w tomie Fragment pamiętnika (Warszawa 1905).

${ }^{13}$ G. Daniłowski, Humoreska, w: idem, Fragment pamiętnika, op. cit., s. 119. Dalej posługuję się skrótem: $\mathrm{H}$. 
gentium, w rodzaju: pospolitego dyfterytu, paciorkowców szkarlatyny, popularnych wysypek kawalerskich czy wreszcie banalnych chorób krajowych, np. liszaja cielęcego, tyfusu brzusznego i suchot. „Przyjaciel Zwierząt” przysyła warczącego gniewnie kundla Katona, wysłanniczka „Dobrej Gospodyni” („przysadzista wieśniaczka z koszem pod pachą” [H, s. 124]) dostarcza zaś „uwiązanego za nogę” prosiaka i czubatą kurę znoszącą mendel jaj dziennie. Kostyczna przedstawicielka „Nowego Pedagoga” („wysoka deskowata dama w binoklach” [H, s. 125]) przyprowadza płaczącą sierotę, by umożliwić sumiennemu prenumeratorowi praktyczną realizację zasad wychowania wpajanych przez pismo li-tylko teoretycznie, a także ułatwić mu ekspiację za szereg lat spędzonych, jak mniema, w rozpuście. Wysłannicy „Przeglądu Felczerskiego” oferują gratisowe strzyżenie, stawianie pijawek i natychmiast golą na łyso głowę gospodarza, wyrywając mu przy okazji dwa zdrowe zęby. Wreszcie cyniczni pracownicy „Dekadenta" przychodzą gremialnie, by pokazać za darmo nagą duszę.

Krótkie, dowcipne scenki rodzajowe, sprawnie kreowane przez Daniłowskiego, budują odpowiednie napięcie dramaturgiczne. Spiętrzenie niecodziennych (wręcz absurdalnych) zdarzeń wywołuje początkowo u odbiorcy uśmiech pobłażania, który rychło przeobraża się w litość i współczucie. Komizm prezentowanych sytuacji wzmacnia komizm postaci, wyolbrzymiający takie cechy charakteru głównego bohatera, jak: głupota, chciwość, naiwność, bierność, nawyki drobnomieszczańskie. Narrator umiejętne rejestruje stopniowe zmiany zachodzące w zachowaniu pana Mateusza, które w końcu prowadzą do destrukcji jego osobowości. Ewolucja nastroju gorliwego subskrybenta najpierw śmieszy, a potem budzi zaniepokojenie odbiorcy. W trakcie rozwijania się akcji obserwujemy różne stany bohatera: od „mruczącego zadowolenia”, zażenowania i zakłopotania - przez radosne wzruszenie, zdezorientowanie i przerażenie - po histeryczne roztkliwienie, depresyjną wściekłość i desperacką arogancję.

Z komizmem sytuacyjnym i charakterologicznym współgra komizm językowy, który dopełnia humorystycznej wizji całości. Budują go: żarty słowne (na przykład zarazki chorobowe są ,w najlepszym gatunku” [H, s. 124]), dowcipne powiedzonka (jak: "delegat «Muchy» pęka z loskotem ze śmiechu” [H, s. 128]) czy zabawne dialogi w rodzaju poniższej rozmowy wychowawczej z czteroletnim dzieckiem, ośmieszającej pedagogiczne kwalifikacje nauczycielki:

- Co robi kura?

- Kura gdacze.

- Dlaczego kura gdacze?

— Kura gdacze dlatego, że znosi jajko.

- A co ona zrobi z tym jajkiem?

- Ona zrobi to, że siądzie.

- Co się weźmie $\mathrm{z}$ tego jajka?

- $\mathrm{Z}$ tego jajka weźmie się kurczę. 
—A ty skądeś się wzięła?

- Wzięłam się z jajka.

- Dobrze! [H, s. 126]

Jak przystało na konwencje gatunkowe humoreski, zabawna historia pana Mateusza rozwiązana jest zaskakująco. Doprowadzony do ostateczności, rzuca się z furią na policjantów, okładając ich „kwiczącym i wyjącym orężem” [H, s. 129], przekonany, że są przedstawicielami kolejnej redakcji, po czym trafia do Tworek i podczas rozmowy z psychiatrą pożera z pianą na ustach dziennik leżący na biurku lekarskim. Nasilające się z czasem objawy ciężkiej choroby psychicznej (bohatera opanowuje obsesja, że ,jest licho oprawnym tomem «Biblioteki Dzieł Wyborowych», którego nikt czytać nie chce" [H, s. 130]), prowadzą wreszcie do śmierci pacjenta. Opowiadanie zwieńcza ironiczna puenta:

Na prima aprilis [...] zajechał antykwariusz hurtownik i złożoną w skrzyni makulaturę jego ciała wywiózł na Bródno. Redakcja niebieska przyjęla go prawdopodobnie przychylnie, bo cierpiał. Ziemskie za to odpłaciły mu się czarną niewdzięcznością: o zgonie jego nie było żadnej wzmianki [...]. I tak nieodżałowanej i świętej pamięci prenumerator, który za cały rok z góry płacil, pozbawiony wszelkiej reklamy, niby sztuka niezależnego autora - zrobił ostateczną klapę — a mogiła jego, szybciej niż sława kurierkowa, uległa zapomnieniu [H, s. 131].

Zagadnienie ulotnej „sławy kurierkowej” i zgubnego wplywu tandetnej prasy na niewyrobionych czytelników Daniłowski roztrząsal jeszcze wielokrotnie w swych tekstach publicystycznych.

Jedną z kardynalnych wad codziennej prasy warszawskiej była — zdaniem publicysty - jej bezideowość, niewybaczalna zwłaszcza w okresie poprzedzającym rewolucję 1905 roku, kiedy społeczeństwo polskie pogrążone w apatii politycznej „nie chciało nic chcieć, nigdzie iść"14. Triumfowały wówczas na rynku bezprogramowe brukowce, w rodzaju kronikarskiego „Kuriera Warszawskiego”, podające informacje o rzeczach mało istotnych, zamiast wskazywać konstruktywny program działania. Daniłowski stwierdzał sarkastycznie:

Dzięki błyskotliwym artykułom „Kuriera” społeczeństwo wiedziało, co się dzieje w buduarach, salonach, za kulisami teatru, ale nie domyślało się, o czym mówią szpulki przędzalni, o czym huczą młoty dolnej i górnej Warszawy, co pełga w plomieniach hut. Nie wiedziano, że na licz-

\footnotetext{
${ }^{14}$ Idem, Sylwetka spoteczeristwa po roku 63-im, w: idem, Fragmenty, Kraków 1914, s. 33.
} 
nych krosnach Pabianic, Łodzi i Żyrardowa tkają się wzory nowego życia, że w gorących potokach żelaza wylewa się płomień rewolucji ${ }^{15}$.

Ten najpoczytniejszy dziennik warszawski, zyskując rychło zasięg ogólnopolski, stawal się niezbędnym organem dla tych wszystkich, którzy interesowali się życiem stolicy. Docierając głównie do mieszczaństwa i inteligencji, pełnił wobec nich funkcję istotnej instytucji użyteczności publicznej. Jak dowcipnie zauważa jeden z bohaterów Jaskótki:

gdyby Warszawski nie wyszedl, wybuchła by u nas rewolucja, na barykady by szli emeryci, jak jeden mąż. Wszystko naród wytrzyma, ale braku $\mathrm{Ku}$ riera — co to, to nie! [J, s. 366].

Podobnie niechętny stosunek miał publicysta do „Kuriera Porannego” — ośmieszał nie tylko jego apolityczność i ideową bylejakość, ale także brak ambicji oddziaływania na poglądy czytelników w zakresie spraw artystycznych. „Poranny” więcej dbał bowiem o drobiazgowe zapowiedzi mających się ukazać książek czy informacje o odbytych koncertach i wystawianych sztukach teatralnych niż o ich fachową ocenę. Ukazujące się na łamach pisma recenzje, objaśniające przede wszystkim treść dzieł (a nie formułujące profesjonalne oceny), nie kształtowały gustów niewyrobionych odbiorców, żądnych jedynie mrożącej krew w żyłach sensacji. Już sama stylistyka redakcyjnych wypowiedzi budzila wiele zastrzeżeń; jak pisał z perspektywy kilkudziesięciu lat Witold Giełżýnski:

„Poranny” nie przebierał w słowach, byl krzykliwy i ordynarny, jak „gazeciarze", którzy go sprzedawali. Polemizując stosowal do przeciwników takie epitety, jak „cymbaly”, „ślepcy”, ,naiwni”, postępowanie ich kwalifikowal jako „bezczelność”, „tandeciarstwo”, „liche sztuczki”, „elukubracje pomylonych" ${ }^{16}$.

Nieprzygotowanych ideowo, pogrążonych w myślowym letargu mieszkańców Warszawy zaskoczył wybuch wojny rosyjsko-japońskiej, który stworzył doskonałą koniunkturę dla prasy. Stołeczne tygodniki o treści ogólnej, związane z chwilą bieżącą, w przeciwieństwie do prasy codziennej, zróżnicowały się pod względem politycznym na: lewicowe (na przykład „Glos”, Prawda”, „Przegląd Tygodniowy”, „Robotnik”, ”Ogniwo”, „Przedświt”), prawicowe (jak „Rola”, „Kronika Rodzinna”, „Biesiada Literacka”) oraz neutralne, tzw. pisma centrum (na przykład „Tygodnik Ilustrowany”, „Wędrowiec”, „Bluszcz”, „Gazeta Domowa”, „Niwa Polska”). Pisma z ostatniej grupy

\footnotetext{
${ }^{15}$ Ibidem, s. 34.

${ }^{16}$ W. Giełżyński, Prasa warszawska 1661-1914, op. cit., s. 339.
} 
nie zaintrygowały Daniłowskiego na tyle, by stać się przedmiotem jego wypowiedzi publicystycznych. Prasę lewicową traktował zawsze bardzo poważnie, pod pręgierzem satyry ustawiał natomiast tygodniki prawicowe, co też i nie dziwi w wypadku zdeklarowanego socjalisty, konsekwentnego ideologa PPS-Frakcji Rewolucyjnej, do końca życia wiernego linii programowej marszalka Piłsudskiego. Redaktorom i wspólpracownikom pism propagujących ideologię endecji wytykał zatem: ugodowość, bierność (sprowadzającą się do taktyki „napadniętego żółwia, który cofa się w swoją skorupę” ${ }^{17}$ ), karygodną dwulicowość, a przede wszystkim hamowanie budzącej się z uśpienia woli walki narodu i popularyzowanie postawy biernego oporu i legalizmu, doprowadzającej wreszcie „do kornego podstawiania pleców pod nahajkę"18 i haniebnego lojalizmu.

Daniłowski nie poprzestał na satyrycznej prezentacji „kurierkowej” prasy warszawskiej, obnażając jej bezideowość, frazesowość, tendencyjność, nastawienie na sensacyjną informację i skandal, a wreszcie manipulowanie gustami odbiorców. Nie ograniczył się do teoretycznego wyrażania krytycznej postawy wobec obcych mu ideologicznie pism prawicowych. Jak przystało na człowieka czynu, próbował czynnie zaradzić chorej sytuacji i ją, przynajmniej w pewnym stopniu, zrównoważyć. Założył i redagował wlasne czasopisma: w Warszawie, w 1908 roku bojowy dwutygodnik społeczno-polityczny i artystyczno-literacki „Witeź” ${ }^{19}$, którego charakterystyczna szata graficzna (na okładce widniała postać średniowiecznego rycerza, w pełnym uzbrojeniu, wspartego na mieczu, z zarysem pary skrzydeł w tle) symbolizowała wolnościową ideologię członków redakcji, oraz we Lwowie, w latach 1910-1911 tygodnik polityczno-społeczno-literacki „Życie”, na którego łamach propagował między innymi ideę strzelecką.

Powyższa prezentacja utworów autora Jaskótki, w których ośmieszeni zostali literaci i prasa warszawska, pokazuje rozległe możliwości pisarza w posługiwaniu się narzędziem satyry i umiejętność korzystania z jej różnorodnych chwytów: od wywołujących śmieszność prostych efektów komicznych, przez karykaturalne przerysowywanie postaci i sytuacji, do budzących zaniepokojenie zabiegów groteski. I choć, jak zaznaczyłam na początku, satyra nie należała do ulubionych form wypowiedzi Danilowskiego, jedno pozostaje poza dyskusją: jako twórca, publicysta i redaktor starał się sam pisać i działać w taki sposób, by w krzywym zwierciadle nie oglądać przynajmniej własnych ułomności artystycznych.

${ }_{17}$ G. Daniłowski, Sylwetka społeczeństwa..., op. cit., s. 52.

${ }_{18}$ Ibidem, s. 24-25.

19 Pismo ukazywało się w Warszawie przez pierwsze półrocze 1908 (wyszło 12 zeszytów). Jego wydawcą i redaktorem nominalnym był Henryk S. Pytliński. Radykalny profil polityczny dwutygodnika zbliżony był ideologiczne do PPS-Frakcji Rewolucyjnej. Współpracowali z nim wybitni artyści, m. in.: Wacław Sieroszewski, Maria Konopnicka, Bolesław Leśmian, Antoni Lange, Władysław Orkan, Jan Lemański, Zofia Nałkowska. Szczupłe zasoby finansowe redakcji spowodowały jednak rychłe zamknięcie "Witezia”, toteż nie wpłynął on w jakiś szczególny sposób na warszawskie środowisko literackie. 